\title{
DETECTION OF MYCOPLASMA PULMONIS IN LABORATORY RATS
}

\author{
Maria Lucia Barreto ${ }^{1 *}$; Elmiro Rosendo do Nascimento ${ }^{1}$; Carlos Augusto de Martino Campos ${ }^{1}$; \\ Maria da Graça Fichel do Nascimento ${ }^{2}$; Gilberto Brasil Lignon ${ }^{3}$; Marie Luce Flores Lira ${ }^{1}$; Ricardo G. Silva ${ }^{1}$ \\ ${ }^{1}$ Universidade Federal Fluminense, Niterói, RJ, Brasil. ${ }^{2}$ Embrapa Agroindústria de Alimentos, Rio de Janeiro, RJ, Brasil. \\ ${ }^{3}$ Embrapa Agrobiologia, Seropédica, RJ, Brasil.
}

Submitted: November 20, 2001; Returned to authors for corrections: April 08, 2002; Approved: August 30, 2002

\begin{abstract}
This work was conducted on rats in two premises located in Niterói and Rio de Janeiro, Brazil. One is classified as conventional controlled and the other, conventional. The objective of the present study was to detect the presence of Mycoplasma pulmonis in animals with symptoms of respiratory disease and low reproductive performance. In the conventional controlled premises, 16 rats of Wistar-Furth strain were necropsied while in the conventional premises necropsy was performed on 12 rats of Hooded Lister strain. The clinical samples of lungs, trachea, oropharynx, middle ear, uterus and ovaries were subjected to culturing while the sera were tested for antibody detection. From 28 rats, 57.14\% (16/28) were culture positive for $M$. pulmonis, being $81.25 \%$ (13/16) from the conventional controlled premises, and $25.00 \%(3 / 12)$ from the conventional premises. The ELISA test was carried out in 20 animals of both colonies. In the conventional controlled premises, $92.86 \%$ (13/14) were positive for M. pulmonis, and $7.14 \%$ (1/14) were suspicious, while in the conventional premises, $100 \%$ (6/6) of the samples were positive. The results confirmed that $M$. pulmonis was the etiologic agent of the disease that affected the rats under study, and that the ELISA positivity rated higher than culture.
\end{abstract}

Keys words: Mycoplasma pulmonis, diagnosis, isolation, serology, rats.

\section{INTRODUCTION}

Rats and mice are used world wide in biological research (14). As to their microbial content, these animals are classified in gnotobiotic, SPF (Specific Pathogen Free) and conventional. The first ones are maintained in colonies with biosecurity barriers and the last ones in environments that allow for a unknown microbiota (24). The sanitary and genetic standardization of these animals supply the researcher important models for the understanding of biological mechanisms in the study of human and animals diseases. However, these animals may be infected by mycoplasma or other microorganisms that interfere on rats and mice production, and, consequently, in the result of any experimental model $(6,15)$.

In Brazil, since the decade of 60, Torres (23) and Vieira (25), pioneers in the use of isogenic strains and germ-free rodents, respectively, initiated the use of laboratory animals with defined genetic and sanitary patterns.

M. pulmonis is the agent of Murine Respiratory Micoplasmosis (MRM) and genital mycoplasmosis, responsible for respiratory and serious reproductive problems in rats and mice $(6,12,16,21)$. The prevalence of MRM varies from $20 \%$ to $60 \%$ in colonies with biosecurity barriers and is about $100 \%$ in conventional colonies (14). The occurrence of genital mycoplasmosis is considered to be $40 \%$ in conventional colonies $(6,21)$, while in colonies with barriers this occurrence is unknown.

The mycoplasma species isolated from rats and mice are $M$. pulmonis, M. arthritidis, M. neuroliticum, M. collis, M. muris and the strain KE2. M. pulmonis colonizes preferentially epithelium of the respiratory tract of rats and mice $(3,6,8)$. The respiratory and genital manifestations of mycoplasmosis in rats are not specific, but quite suggestive $(3,15)$.

\footnotetext{
* Corresponding author. Mailing address: Universidade Federal Fluminense. Núcleo de Animais de Laboratório. Morro do Valonguinho s/n - Centro. 24210-000, Niterói, RJ, Brasil. Tel.: (+5521) 2618-3346. E-mail: lúcia@vm.com.br
} 
According to Davidson et al. (8), the diagnosis of MRM is not difficult. However, there are difficulties in diagnosing assymptomatic animals, as well as in establishing the differentiation among pathogenic and commensal mycoplasmas. To be successful on mycoplasma isolation from clinical specimens, it is necessary to consider the lesion site, collection procedure, care on transportation, presence of inhibiting growth factors in tissue samples, and the nutritional requirements of the microorganism (10). Cassell et al. (5), Davidson et al. (8) and Simecka et al. (20) suggested that specimens for culturing should be taken from multiple sites in order to favor the isolation. The isolation rates were compared with other diagnostic methods, such as ELISA (11), indirect immunofluorescence (13), hystopathology $(13,19)$ and PCR (19). The culture procedure is simple and very effective for conventional animals, but of limiting value in barrier-maintained colonies (7). Freundt (10) and Davidson et al. (8) reported that culturing is necessary to validate the results obtained by others methods.

In Brazilian breeding facilities, the diagnosis of MRM has been made presumptively, through observation of the symptoms and macroscopic aspects of the lungs. Rossini et al. (18) isolated Mycoplasma spp. from mice with pneumonia and arthritic problems in the Municipality of São Paulo, SP, Brazil. Thereafter, Timenesky et al. (22) also isolated M. pulmonis and $M$. arthritidis in rats and mice originating from conventional colonies in the same location.

The present work aimed to detect mycoplasmas in conventional rat colonies with and without biosecurity barriers, presenting respiratory disease and significant decrease in productivity, in two breeding facilities in Rio de Janeiro, Brazil.

\section{MATERIALS AND METHODS}

\section{Animals}

Twenty-eigth mice from two breeding facilities in Rio de Janeiro and Niterói cities, RJ, Brazil, were studied. Sixteen of them were obtained from a conventional controlled and 12 from conventional premises. The rats from the controlled conventional premises belonged to Wistar-Furth stock, with ages ranging from 6 to 12 months (10 females and six males), and presented respiratory symptoms. Although specimens from the middle ear were collected, through ear flushing, only one had labyrinthitis signs. The rats from the conventional premises were of the Hooded Lister strain, with ages ranging from 10 to 12 months, and also presented respiratory disease denoted by sneezes. Nasal and ocular secretion were collected from these animals. The most severely ill rats presented weight loss, ruffled coat and low productivity.

\section{Samples collection}

After anesthesia with sodic pentobarbital in the dose of $0.06 \mathrm{mg} / \mathrm{g} \mathrm{(4)}$, the rats were bled by the intra-cardiac route, using vacutainers for collection of the serum. After, there they were sacrificed with overdose of this anesthetic and necropsied. Lung fragments, trachea and ear washings were collected from rats of the controlled conventional premises. Lung, trachea, uterus and ovary fragments and swab of oropharynx of the rats obtained in the conventional premises were used for mycoplasma isolation. Fragments of the same organs were used for the histopathologic diagnosis.

\section{Culturing and colony observation}

Tissues samples were homogenized, macerated in mortars and pestles with sterile sand, and centrifuged. The supernatant and the liquid from flushing and "swabs" were cultured in liquid and solid Medium A for Murine Mycoplasmas, $\mathrm{pH} 7.8$, containing equine serum and DNA, and incubated at $37^{\circ} \mathrm{C} \mathrm{(8)}$. The plates were incubated in humid and microaerophilic atmosphere, in candle jars. The presence of mycoplasma colonies on plates were observed daily up to 21 days, using a stereomicroscope (4). The mycoplasma colonies were characterized by the Dienes staining method and typed (9).

\section{Mycoplasma identification}

Indirect Fluorescent Antibody (IFA) method was used for identification of six of the 16 clinical isolates. Colony imprints, used as IFA antigen, were made by topping each agar block medium with colonies side up, with coverslip, followed by removal, drying at room temperature, and storage at $-20^{\circ} \mathrm{C}(1)$. Rabbit anti-M. pulmonis serum, obtained as described in the literature (8), and the respective anti-serum conjugated with fluorescein (SIGMA) were used. The reference strain of $M$. pulmonis PG 34, kindly supplied by Dra. Gail Cassell, Department of Microbiology, University of Alabama, Birminghan, Alabama, USA, was the positive control while $M$. gallisepticum and $M$. arthritidis were used as negative controls. The serologic diagnosis of M. pulmonis was performed by ELISA test as previously described (2).

The statistical differences from positive proportions among the diagnostic procedures used were analyzed by qui-square method (17).

\section{RESULTS}

As a result of culturing the clinical specimens, colonies of mycoplasma resembling raindrops on glass were obtained (Fig. 1). The isolates were included in the Mollicutes class, as the colonies were dark blue by Diene's staining, and fermented glucose. Colony imprints from these clinical isolates presented greenish fluorescence under the FA microscope, and were typed as M. pulmonis by the IFA method (Fig. 2).

M. pulmonis was recovered from all types of specimens collected from rats in both conventional controlled premises (lung, trachea, and middle ear) and conventional premises (lungs, trachea, 


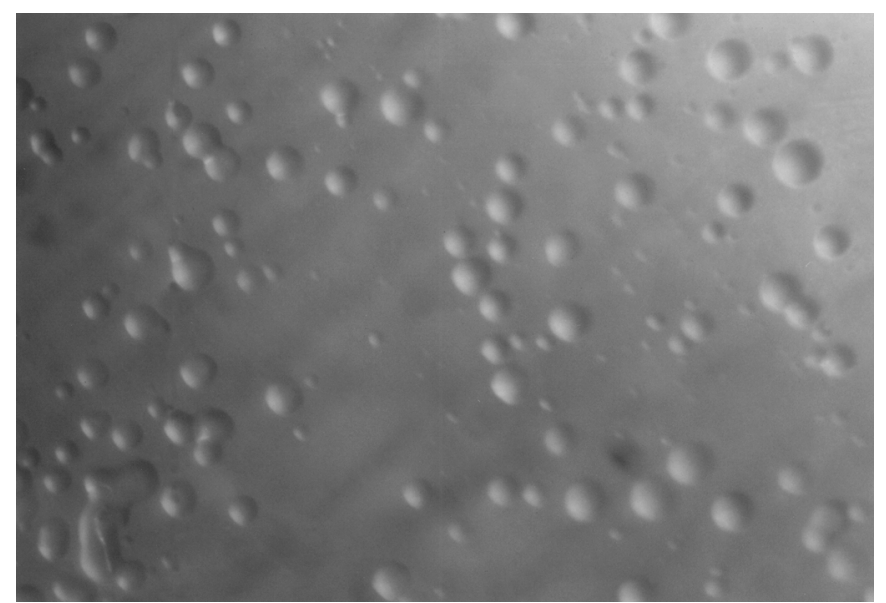

Figure 1. M. pulmonis from lungs homogenate on solid medium. Vizualization under stereomicroscope (40X).

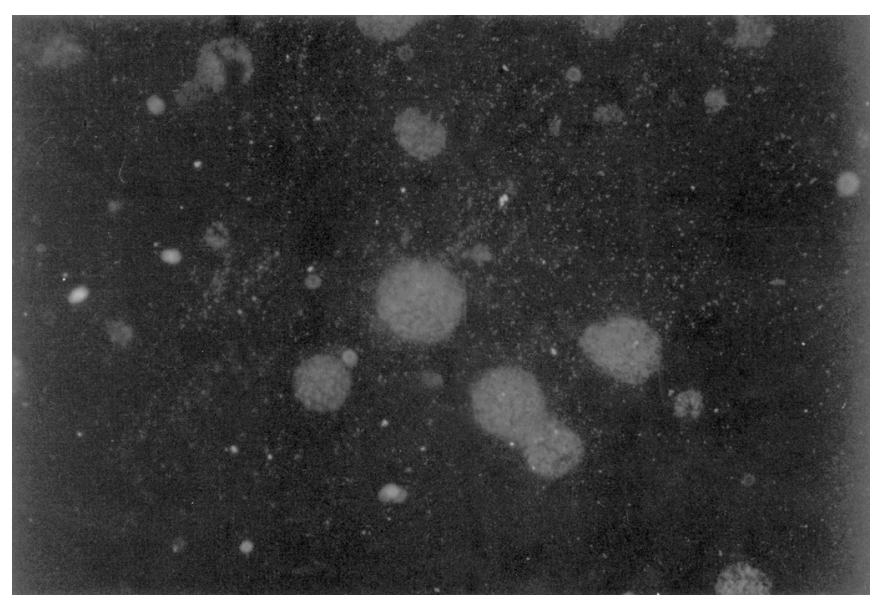

Figure 2. Cover slip impression of mycoplasma colonies from lungs homogenate typed as $M$. pulmonis by the indirect immunofluoresce method (100x).

uterus, ovaries, and oropharynx). Only five animals were $M$. pulmonis positive in all organs, two from the conventional controlled and three from the conventional premises.

The culturing of a large variety and number of organs lead to the isolation of mycoplasmas in 13 out of 16 rats from the conventional controlled premise while only three positive results were obtained from 12 rats from the conventional premise (Fig. 3 ). From the cultured clinical specimens, $57.14 \%$ (16/28) were positive by isolation, $95.00 \%(19 / 20)$ by ELISA, being one considered suspect, and $73.68 \%$ (14/19) by both tests (Table 1). As to the isolation percentage, the highest positivity rate $(81.25 \%)$ was obtained in rats from the conventional controlled premise followed by those from both premises $(57.15 \%)$ and by those from the conventional premise $(25.00 \%)$ (Table 1$)$.
Using ELISA the highest positivity rate was yielded by rats from the conventional premise (100\%), followed by rats from both sanitary patterns $(95.00 \%)$ and then by rats from the conventional controlled premise (92.86\%). The ELISA test was more sensitive than the isolation method being the greatest difference observed in the conventional premise, where the isolation coefficient was much lower than that by ELISA (Table 1; Fig. 4).

The proportion of positive results using the three diagnostic procedures was statistically different $(\mathrm{P}<0.0001)$. The best performance was achieved by ELISA, followed by both procedures, and, finally by culturing.

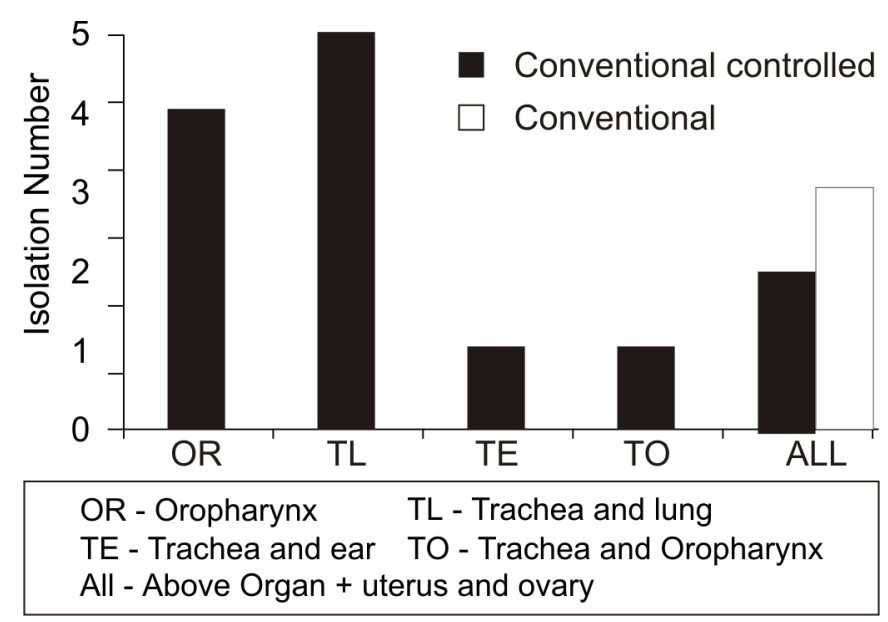

Figure 3. Incidence of M. pulmonis in organ tissues of rats from conventional controlled and conventional premises.

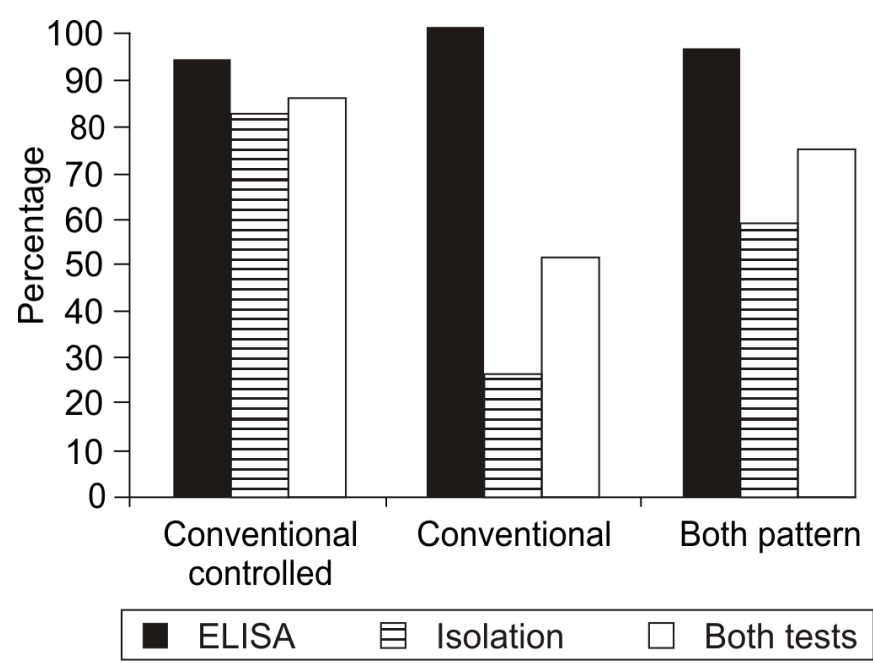

Figure 4. Sensitivity of the methods used for the diagnosis of M. pulmonis in rats*.

$*$ - $\chi^{2}$ statistically significant $(\mathrm{P}<0.0001)$. 
Table 1. Positivity for M. pulmonis in rats from premises with different sanitary patterns, according to detection test.

\begin{tabular}{ccccrrr}
\hline $\begin{array}{c}\text { Detection } \\
\text { test }\end{array}$ & \multicolumn{2}{c}{$\begin{array}{c}\text { Conventional } \\
\text { Controlled }\end{array}$} & \multicolumn{2}{c}{ Conventional } & \multicolumn{2}{c}{ Both } \\
\hline Isolation & $13 / 16$ & 81.25 & $03 / 12$ & 25.00 & $16 / 28$ & 57.15 \\
ELISA & $13 / 14$ & 92.86 & $06 / 06$ & 100.00 & $19 / 20$ & 95.00 \\
Both tests $^{\mathrm{b}}$ & $11 / 13^{\mathrm{c}}$ & 84.62 & $03 / 06$ & 50.00 & $14 / 19$ & 73.70 \\
\hline
\end{tabular}

$*-\chi^{2}$ statistically significant $(\mathrm{P}<0.0001)$; a- Positive/tested and $\%$; b- Combining both diagnostic procedures, the numerators express the positive agreement between them; $\mathrm{c}$ - One suspicious sample.

\section{DISCUSSION}

As the present study aimed to diagnose MRM and as the prevalence of this disease in conventional facilities is 100\% (14), there was no need of a large number of animals for investigation. For the same reason, only part of the isolates were subjected to typing by IFA for identification of the etiologic agent.

The isolation rate obtained for M. pulmonis, $57.14 \%$ (16/28), was higher than that described by Sanchez et al., (19), and in accordance with Kraft et al. (13) and Simecka et al. (20).

Negative cultures were obtained in $42.90 \%$ (12/28) of the specimens. From these negative rats, six of them yielded positive result in the ELISA test. Freundt (10) and Davidson et al. (8) reported that culturing is necessary for validation of results obtained by other methods. The result of this study suggests that the rats, although negative by isolation, were infected by M. pulmonis.

Although specimens from the uterus and ovaries were collected only from animals of the conventional premise and cultured for mycoplasma, three MRM positive rats from this group presented genital mycoplasmosis, showing the association between these infections. These results are in accordance with affirmatives of Cassell, $(3,8)$; Simecka et al., (20) and Steiner and Brown (21).

Isolation of M. pulmonis from rats with clinical diseases is not difficult, but associations of viral and bacterial infections of primary or secondary character can intensify the lesions and interfere in the isolation (7). This probably explains why the isolation rate in the conventional premise, even culturing all organs, was lower than in the conventional controlled premise, as shown in Table 1 and Fig. 4.

In this study, the culturing of several organs increased the chance of mycoplasma isolation $(8,10,20)$. In severe lesions, common in the conventional premises, the isolation rate is lowered by the interference of contaminants and debris, as shown by Cassell et al. (5); Davidson et al. (7); Davidson et al. (8); Simecka et al. (20).
According to the qui-square analyses, the sensitivity of ELISA was higher than the isolation procedure, which agrees with the literature in relation to false negative results given by the last diagnostic procedure $(8,10,20)$. ELISA has good sensitivity and specificity when utilized for diagnosis of MRM (11), as confirmed by the results of $100 \%$ and $92.86 \%$ positivity, respectively, for conventional and conventional controlled premises.

IFA, using cover slips, was simple and yielded good results, confirming its application for tipification of M. pulmonis, as described by Al-aubaidi and Fabricant (1).

This study detected the presence of M. pulmonis in the two premises and reaffirmed the observations of Timenesky et al. (22), who concluded that the prevalence of mycoplasmosis in rats of São Paulo reflects the situation in the whole country. However, M. arthritidis was not isolated or even suspected in the studied animals.

\section{RESUMO}

\section{Detecção de Mycoplasma pulmonis em ratos de biotérios}

O presente estudo foi desenvolvido em ratos de dois biotérios, um em Niterói e outro no Rio de Janeiro, sendo um classificado como convencional controlado e o outro como convencional. O objetivo foi verificar a presença do Mycoplasma pulmonis em animais que apresentavam sintomas de doença respiratória e baixa produtividade. No biotério convencional controlado foram necropsiados 16 ratos da linhagem WistarFurth enquanto no biotério convencional a necrópsia foi realizada em 12 ratos da linhagem Hooded Lister. Os espécimes de pulmão, traquéia, orofaringe, ouvido médio, útero e ovário foram submetidas ao cultivo e o soro obtido ao teste de ELISA. Dos 28 ratos que foram submetidos ao cultivo para micoplasmas, $57,14 \%$ (16/28) foram positivos para M. pulmonis sendo $81,25 \%$ (13/16) provenientes do biotério convencional controlado, enquanto no biotério convencional a taxa foi de $25,00 \%$ (3/12). O teste de ELISA foi realizado em soro de 20 animais, de ambos os biotérios, verificando-se que no biotério convencional controlado, $92,86 \%$ (13/14) dos ratos examinados, foram positivos enquanto $7,14 \%$ (1/14) foram considerados suspeitos. No biotério convencional, $100 \%$ (6/6) dos ratos foram positivos. Esses resultados confirmaram que M.pulmonis era o agente etiológico da doença respiratória que acometia os animais estudados e que a sensibilidade do ELISA foi maior do que a do isolamento.

Palavras-chave: Mycoplasma pulmonis, diagnóstico, isolamento, sorologia, ratos. 


\section{REFERENCES}

1. Al-Aubaidi, J.M.; Fabricant, J. The practical application of immunofluorescence (agar block technic) for the identification of mycoplasma. Corn. Vet., 61: 581-596, 1971.

2. Campos, C.A.M.; Nascimento, E.R.; Barreto, M.L.; Nascimento, M.G.F.; Verícimo, M.A. Rev. Brasil. Med. Vet., 22: 207-209, 2000.

3. Cassell, G.H. The pathogenic potential of mycoplasmas: Mycoplasma pulmonis as a model. Rev. Infec. Dis., 4: 18-34, 1982

4. Cassell, G.H.; Davidson, M.K.; Davis, J.K.; Lindsey, J.R. Recovery and Identification of Murine Mycoplasmas. In: Tully, J.G.; Razin, S. (eds.) Methods in Mycoplasmology: Diagnostic Mycoplasmology Academic Press, New York, 1983, p.129-142.

5. Cassell, G.H.; Davis, J.K.; Cox, N.R.; Davidson, M.K.; Lindsey, J.R. Mycoplasma pulmonis detection in rodents: Lessons for diagnosis in other species. Isr. J. Med. Sci., 20: 859-865,1984.

6. Cassell, G.H.; Lindsey, J.R.; Davis, J.K. Respiratory and genital mycoplasmosis of laboratory rodents: implications for biomedical research. Isr. J. Med. Sci., 17: 548-54,1981.

7. Davidson, M.K.; Lindsey, J.R.; Brown, MB. Comparison of methods for detection of Mycoplasma pulmonis in experimentally and naturally infected rats. J. Clin. Microb., v.14, 1981, p.646655 .

8. Davidson, M.K.; Davis, J.K.; Gambill, G.P.; Cassell, G.H.; Lindsey, J.R. Mycoplasmas of Laboratory Rodents. In: Whittford, H.W.; Rosenbusch, R.F.; Lauerman, L.H. (eds.). Mycoplasmosis in animals: Laboratory diagnosis. Iowa State University Press, Ames, Iowa, 1994. p.39-50.

9. Dienes, L. Morphology and nature of the pleuropneumonia group of organism. J. Bacteriol., 50: 441-458, 1945.

10. Freundt, E.A. General principles of laboratory diagnosis of Mycoplasma infections. Isr. J. Med. Sci., 17: 641- 643, 1981.

11. Horowitz, S.A.; Cassell, G.H. Detection of antibodies to Mycoplasma pulmonis by na enzyme-linked immunosorbent assay. Infect. Immun, 22: 161-70, 1978.

12. Kohn, D.F.; Kirk, B.E. Pathogenicity of Mycoplasma pulmonis in laboratory rats. Lab. Anim. Care, 19: 321-330, 1969.

13. Kraft, V.; Meyer, B.; Thunert, A.; Deerberg, F.; Rehm, S. Diagnosis of Mycoplasma pulmonis infection of rats by indirect immunofluorescence test compared with 4 other diagnostic methods. Lab. Animl. Sci., 16: 369-73, 1982.
14. Lindsey, J.R. Prevalence of viral and mycoplasmal infections in laboratory rodents, In: Bhatt, P.N.; Jacoby, R.O.; Morse Iii, H.C.; New, A.E. (eds.). Viral and mycoplasmal infections of laboratory rodents. Academic Press, New York, 1986b. p.801-808.

15. Lindsey, J.R.; Baker, H.J.; Overcash, R.G.; Cassell, G.H.; Hunt, C.E. Murine chronic respiratory disease. Significance as a research complication and experimental production with Mycoplasma pulmonis. Amer. J. Pathol., 64: 675-717, 1971.

16. Lutsky, I.I.; Organick, A.B. Pneumonia due to mycoplasma in gnotobiotic. I Pathogenicity of Mycoplasma pneumoniae, Mycoplasma salivarium and Mycoplasma pulmonis for the lungs of conventional and gnotobiotic mice. J. Bacteriol., 92: 1154-63, 1966.

17. Martin, S.W.; Meek, A.H.; Willeberg, P. Sampling methods. In: Veterinary Epidemiology. Principles and methods. Iowa State University Press, Ames, IA. 1994, 348p.

18. Rossini, A.J.; Nikitin, T.; Fuchs, H. Isolamento de Mycoplasma sp. de Rattus sp. Acometidos de pneumonia doença natural. In: XII Congresso Latino Americano de Microbiologia \& Congresso Brasileiro de Microbiologia, 1983, São Paulo. Anais. São Paulo: 1983, p.57.

19. Sanchez, S.; Tyler, K.; Rozengurt, N.; Lida, J. Comparison a PCRbased diagnostic assay for Mycoplasma pulmonis with traditional detection techniques. Lab. Anim., 28: 249-256, 1994.

20. Simecka, J.W.; Davis, J.K.; Davidson, M.K.; Ross, S.E.; Stadtlander, C.T.K.H.; Cassell, G.H. Mycoplasma diseases of animals. In: Mawiloff, J., Mc Echaney, Finch, Baseman. (eds.) Mycoplasmas-Molecular Biology and Pathogenesis. Academic Press, New York, 1992, p.391-411.

21. Steiner, D.A.; Brown, M.B. Impact of Experimental genital mycoplasmosis on pregnancy outcome in sprague-Dawley rats. Infect. Immun., 61, 2: 633-639, 1993.

22. Timenetsky, J.; Summa, M.E.L.; Lucca, R.R. Mycoplasma pulmonis and Mycoplasma arthritidis in rodents from animal houses. Braz. J. Vet. Res. Anim. Sci., 29,1: 45-50, 1992.

23. Torres, S.T.; Pinto, O.S.; Paula, E.F.; Klaczko, L.B. Coxsackie virus susceptibility of newborn mice of different isogenic strains. Rev. Bras. Biol., 37: 357-361, 1977.

24. Trexler, P.C. Animals of defined microbiological status In: Poole, T.B. (eds.) The UFAW handbook on the care \& of laboratory management animals. Londres, 1989, p.85-98.

25. Vieira, E.C.; Nicoli, J.R.; Silva, M.E.; Costa, C.A.; Mayrink, W.; Bambirra, E.A. Cutaneous Leishmaniasis in Germfree, Gnotobiotic and Conventional Mice. Rev. Inst. Med. Trop., São Paulo: 29(6): 385-387, 1987. 